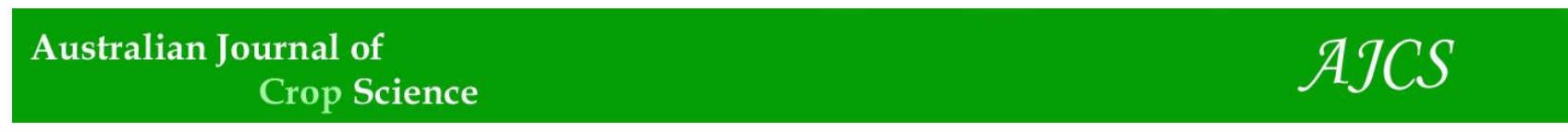

AJCS 10(12):1649-1654 (2016)

ISSN:1835-2707

doi: 10.21475/ajcs.2016.10.12.p7444

\title{
Occurrence and control of root knot nematode in crops: A review
}

\author{
Nurul Hafiza Al Abadiyah Ralmi, Mohammad Moneruzzaman Khandaker*, Nashriyah Mat \\ School of Agriculture Science and Biotechnology, Faculty of Bioresources and Food Industry, University of \\ Sultan Zainal Abidin, Besut Campus, 22000 Besut, Terengganu, Malaysia
}

*Corresponding author: moneruzzaman@unisza.edu.my

\begin{abstract}
Root-knot nematode (RKN) which comes from Meloidogyne species is an obligate, parasitic nematode which can be found in varieties of plants, considered as a host to that particular nematode. Their potential host range encompasses more than 3000 plant species. The presence of RKN in the crops becomes one of the major problems nowadays because they cause great agriculture loss. Among the many genera of nematodes having some economic impact, Meloidogyne spp. are responsible for a large part of the annual 100 billion dollar losses attributed to nematode damage. This review discussed on mechanism of infection of RKN, the presence of RKN in different kind of crops, and the importance of an intergrated approach used in Meloidogyne spp. management strategies. Meloidogyne spp. management strategies.
\end{abstract}

Keywords: Crops, integrated approach, meloidogyne, obligate, root knot nematode. Abbreviations: RKN_root knot nematode.

\section{Introduction}

Root-knot nematodes (Meloidogyne species) are microscopic and parasitic nematodes which can be found in the roots of infected plants. Under Meloidogyne genus, there are about 98 species and common species encountered by farmers were $M$. incognita, M. javanica, M. hapla, and M. arenaria (Jones et al., 2013) .They can exist either in hot climates or short winters around the world. In a report by Gill and Mcsorley (2011), root-knot nematode is one of the most damaging groups of plant-parasitic nematodes and these nematodes are pests of almost all major crops. In addition, Karajeh et al., (2008), stated that about $5 \%$ of the world crop production is destroyed by Meloidogyne species every year. According to Sasser (1980), more than 2,000 plant species have been designated as hosts to root-knot nematodes, and most cultivated crops are attacked by at least one root-knot nematode species. In 2003, the host range already encompasses more than 3000 plant species (Abad et al., 2003). This shows an increasing number of hosts that have been infected with root-knot nematode. The host range of root-knot nematodes is so extensive that it is difficult to find common crops that are not hosts (Olsen, 2000). The hosts can be vegetables, bedding plants, grasses, shrubs, numerous weeds and trees.

\section{Distribution of Meloidogyne species around the world}

According to Truggill and Blok (2001), M. incognita is easily found in every temperate and tropical country, and it is possibly the single most damaging crop pathogen in the world. RKN are most abundant in the upper foot of soils until a few feet deep (Olsen, 2000). In cool climates where the temperature is around $0^{\circ} \mathrm{C}$ to $15^{\circ} \mathrm{C}$ or above, the most common Meloidogyne species is M. hapla. M. hapla can be found in northern United States, northern Europe, northern
Asia, Southern Canada in North America, and as well as in South America which is specific at latitude $40^{\circ} \mathrm{S}$. While in Africa, it may be found at altitudes above 1500 meters. It is common in Victoria, Australia the southernmost state. For the tropic zone, the most common Meloidogyne species are $M$. incognita and $M$. javanica. These species becomes common as the equator is approached. $M$. javanica is probably the most common Meloidogyne species in many parts of tropical Africa, Australia and southern Asia. Meanwhile, M. incognita and $M$. arenaria are common and widespread in the same regions. Thus, between $35^{\circ} \mathrm{S}$ and $35^{\circ} \mathrm{N}$ latitudes of the world three main species of Meloidogyne were believed to continuous existence in warm countries, which are $M$. javanica, $M$. incognita and $M$. arenaria (Taylor and Sasser, 1978). Therefore, four species of Meloidogyne; M. javanica, $M$. incognita, $M$. hapla, and $M$. arenaria are the most widespread and common Meloidogyne species of the world and most probably cause more damage to farm crops compare to others Meloidogyne species (Sasser, 1977).

\section{Symptoms in infected plants}

Infected plants shows signs of nutrient deficiency such as slow or stunted growth, yellowing of the leaves, wilting of the plant and the worse situation the plant died. Heavy infection of older plants causes the plants to wilt unexpectedly and die off early. As the result of nematode induced expansion of root cells, swellings, or galls develop on the roots of infected plants. The galls vary in size from slight thickenings to lumps 5 to $10 \mathrm{~cm}$ across. Stems or leaves may be galled but this is rarely seen in plants growing outdoors. Galls caused by Meloidogyne hapla are much smaller than those caused by other species. All root knot galls damage the vascular tissues of roots and thus interfere with 
the normal movement of water and nutrients through the plant. They also increase the susceptibility of the root system to be invaded by disease-causing fungi and bacteria (Rahman, 2003). Olsen, (2000) stated that the galls are easy to be identified, however for the RKN to be determined, they are too small and need to be identified under microscope. In addition, diseased plants also may show symptoms of nitrogen, potassium, or phosphorus deficiencies even though adequate levels of these minerals are in the soil. During hot daytime temperature, infected plants wilt and then recover at night. The roots also show characteristic of shorter and bushier than on healthy plants (Tisserat, 2006).

\section{Mechanism of infection}

Abad et al., (2003) stated that RKN are biotrophic parasites which evolved subtle strategies to successfully infest a diversity of plant species. Invasion of the root tissues by RKN involves mechanisms common with plant pathogenic bacteria and fungi, which is the production of cell wall degrading enzymes.

Figure 1 show the complete life cycle of root knot nematode. Infection of root knot nematodes starts with injection secretions into the host plants. In the zone of root elongation, the worms hatch as second-stage juveniles and actively invading the host. They migrate intercellularly to the root apex and then to the vascular cylinder. This is where permanent feeding sites are established and second-stage juveniles undergo three moults to develop into adults. While the females remain sedentary, producing large egg masses, males migrate out from the plant (Abad et al., 2003). Then, the formation of galls will takes place, later on this galls formation will prohibit or only have limited ability to absorb and transport water and nutrients to the plant. This situation will severely affect plants and they will easily wilt. Come to worse situation, the infection takes place at the early stage of plant's development; root-knot nematode can directly kill the host plant.

\section{Host of root-knot nematode}

According to Mitkowsaki and Abawi (2003), host plant species also become one of the factors which contribute to the degree of root galling in plants. Famous crops that usually deal with root knot nematode and have been reported were carrots, lettuce, onions, potato, tomato, and soybeans. In Wesemael and Moenc (2008) report, Meloidogyne chitwoodi (RKN) is widespread in the Belgian Provinces Antwerp and Limburg and the presence of this nematode caused damage to the carrot crop (Daucus carota). Carrots usually undergo severe forking with galling predominantly found on lateral roots. In addition, nematode damage at infection sites may induce secondary development resulting in forked or ramified roots (Boiteux et al., 2000). Root knot nematode parasitized the growing root tip and this result to taproot that became forked, distorted and stunted (Fig 2a). Meanwhile, root-knot nematode galls on lettuce are beadlike shapes (Fig 2b). With the increasing lettuce planting grown under plastic tunnels, nematode attacks become common and increase in population (Maluf et al., 2002). Vianene and Abawi, (2000), reported that the northern root-knot nematode (Meloidogyne hapla Chitwood) is one of the major constraints of lettuce (Lactuca sativa L.) production on organic (muck) soils in New York. The formation of galled root prohibits transferring of sufficient water and nutrients for normal lettuce growth. Lettuce plants heavily infected with $M$. hapla produce small and loose heads that are unmarketable.
For grasses and onions, galls are usually small and only shows a slight swelling (Fig 2c). Root-knot nematode, $M$. hapla infects onion crops by disturbing the growth and development of the plant by causing stunting, thicker necks and smaller bulbs and also delayed maturity (Widmer et al, 1999). In potato crops, RKN cause losses in potato crops by disfiguring the tubers. Infection shows up conspicuously as pimple-like outgrowths on the skin, and the whole surface may become warty and discoloured (Fig 2d). The nematode may be seen using a magnifying glass as a small, glistening body embedded in the tissue if one of the pimple-like outgrowths is cut open (Rahman, 2003).

Tomatoes are host to several species of root-knot nematodes (Meloidogyne species). According to Aegerter (2009), affected areas usually appear as irregular patches and are frequently associated with lighter-textured soils (Fig 2e). Nematodes can also cause damage to crops grow in heavier soils. The range temperature for nematode development is around $64 \mathrm{~F}-90 \mathrm{~F}$. At high temperature above $82 \mathrm{~F}$, the plant resistance is broken down, thus it will ease the nematodes to enter the roots.

In the United States, RKN also cause damage to the soybean crops (Westphal and Xing, 2006). Same to tomato plants, usually RKN prefers light textured soil which has higher sand content. For soybean crops, M. hapla or known as northern root knot nematode and $M$. incognita known as southern root knot nematode are two causal agents that causes damaged to the crops. Soybean plants can be infected at any stage of development. However, it is a bit confusing to differentiate between root knot damage with other soil-related plant growth suppressing factors such as excessive soil moisture or drought at any soybean growth stage, extreme soil $\mathrm{pH}$ values, and radical soil texture differences within a field. Fig $2 \mathrm{f}$ shows root galling on infected RKN soybean plants. Nematode-induced galls consist of globular, irregular deformations compared to normal nodules which develop after infection by beneficial, symbioticbacteria that fix atmospheric nitrogen for the plant and receive photosynthates in return. Root knot nematodes size range from $3.175 \mathrm{~mm}$ to $25 \mathrm{~mm}$ in diameter while normal nodules diameter is around 6-7 $\mathrm{mm}$ attaching outside the roots.

In North Carolina, RKN is the most economically important cucumber disease causing an average annual yield loss of 11\% (St. Amand and Wehner, 1991). M. hapla does not become a problem in North Carolina, however M. hapla become causative agents to the cucumbers grown in Canada (Zimmer and Walkof, 1968). While in experiments conducted by Winstead and Sasser (1956), all cucumber plants were resistant to $M$. hapla and susceptible to $M$. incognita, $M$. javanica, and $M$. arenaria. Fig $2 \mathrm{~g}$ shows an image of galls formation on roots of cucumber plants infested by RKN.

In tropical zone, numerous crops had been reported to have problems with RKN. For example, Kenaf (Hibiscus Cannabinus) was also infected by RKN. In Malaysia, the government encourage farmer to plant Kenaf because these plant contain fibre that can be used to produce various product and these plant also has high economically value. These kenaf plants were planted in the area with former cultivation of tobacco which mostly was in BRIS soil. However, these Kenaf were being prone to nematode infestation because BRIS soil is a suitable medium for nematode to grow and results great loss to farmers. Tahery et al., (2011) reported that the infected kenaf plants which were planted in BRIS soil located at Telaga Papan, Terengganu showed decolorating, drying and wilting of their leaves along 


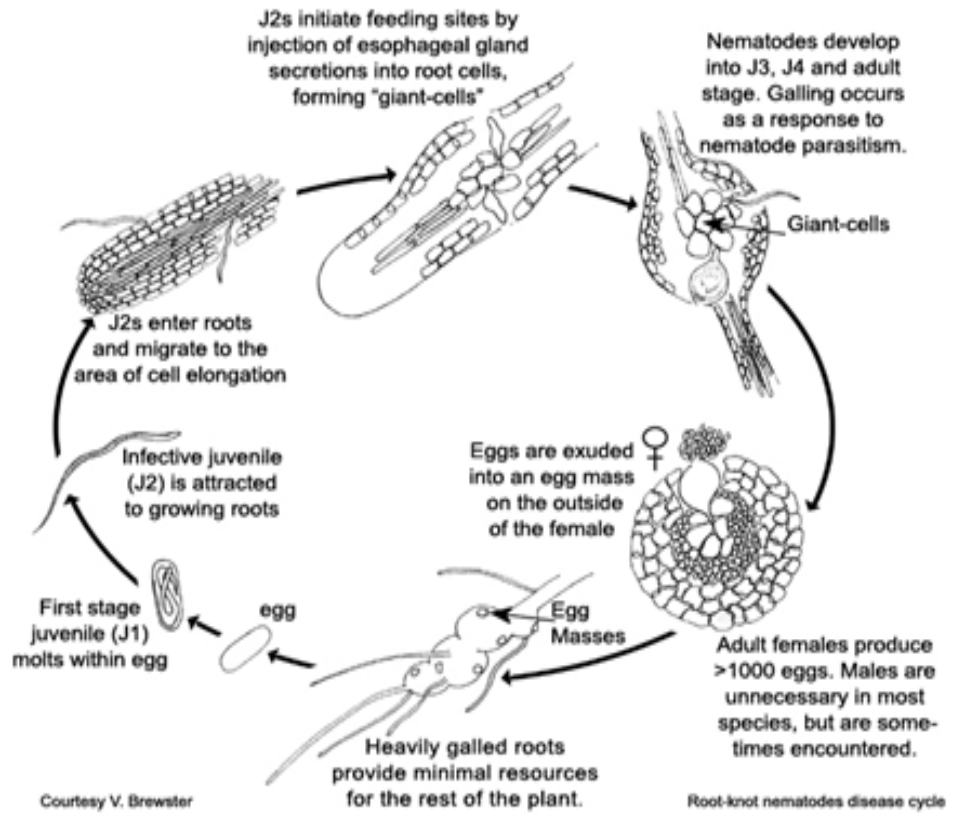

Fig 1. Complete life cycle of root knot nematode Courtesy of V. Brewster. (Mitkowski and Abawi, 2003)

with developing of galls on their root (Fig $2 \mathrm{~h}$ ). The study also showed nematode infestations greatly affected the growth of the plants, quantity as well as quality of Kenaf yield.

The presence of plant-parasitic nematode $M$. graminicola on rice also cause serious loses of rice crops thus threatening food security in India. According to Dutta et al., (2012) M. graminicola Golden and Birchfield, are the most common RKN species that infected rice crops. The traditional paddy rice production requires large amount of water. This becomes one of the limitations in many areas of Southeast Asia as water requirements are too high. It is reported that out of a total area of 79 mha of irrigated paddy rice, 17 mha may experience physical water scarcity and 22 mha economic water scarcities by 2025 (Dutta et al., 2012). Some techniques were implemented to overcome the issue such as direct wet seeding, intermittent irrigation, cultivation on raised beds and the cultivation of aerobic rice varieties. However, De Waele and Elsen (2007) reported that these techniques are favouring the development of high populations of $M$. graminicola. These RKN can survive on upland, lowland and deepwater rice. Fig $2 \mathrm{i}$ shows the hook-like galling on paddy roots which been infected by $M$. graminicola.

\section{Prevention of root-knot nematode}

\section{Cultural control}

Root knot-nematode cause enormous losses to our crops. There are a few ways in preventing root-knot nematode. Meloidogyne control measures can be conveniently divided into two major categories which are using cultural control and chemical control. In cultural control practices, resistant varieties and cover crops become favourable practice to the farmers. Resistant varieties are considered one of the most efficient methods for root-knot nematode (Meloidogyne spp.) control (Ferraz and Mendes, 1992). According to Jenkins (1960), resistant varieties restrict entry or prohibit reproduction of nematode. For instance, vegetable fields infested with $M$. hapla can potentially be planted with a nonhost crop. However, this will reduce the grower's short term incomes (Mitkowsaki and Abawi, 2003). In contrast, crop rotation can be very successful if farmers use an alternative non host crop with high economic return.

\section{Cover crops}

Besides that, cover crops also can be grown outside the normal agricultural growing season. With the presence of cover crops, nematodes cannot migrate to another field if a cover crop is not a host to the nematodes because nematodes can move only a very short distance on their own (Gill and Mcsorley, 2011). A few examples of cover crops are cowpea (Vigna unguiculata), sorghum-sudangrass (Sorghum bicolor $\times S$. sudanense), sunn hemp (Crotalaria juncea) and marigolds (Tagetes spp.). In addition, legumes also can become one of the cover crops because they can supply nitrogen to subsequent crops or can be used as high-quality forage in silage production (Hartwig and Ammon, 2002). There are a lot of advantages by planting cover crops. Cover crops help improve soil fertility, soil structure, decrease soil erosion, and suppress weeds, insects, nematodes, and other plant pathogens.

\section{Soil solarisation}

Another way that can be used to reduce RKN damage is by using a process called soil solarisation (Tisserat, 2006). Solarization is usually done in mid-summer to maximize oil heating effects. The soil is covered with plasticfilm for at least 2 weeks and this killed the egg of the nematode, thus reducing the population of RKN. According to Noling (2009), the most successful use of soil solarization takes place in heavier (loamy to clay soils) rather than sandy soils. Soils with good water holding capacity enhance the heat transfer to deeper soil horizons. Therefore, soil depth affected the number of RKN killed in the roots.

\section{Chemical control}

Chemicals used to control nematodes can be divided into three types: nonfumigant nematicides, fumigant nematicides, and multipurpose fumigants (Noling, 2012). Nonfumigant nematicides need to be uniformly distributed to the soil in a 


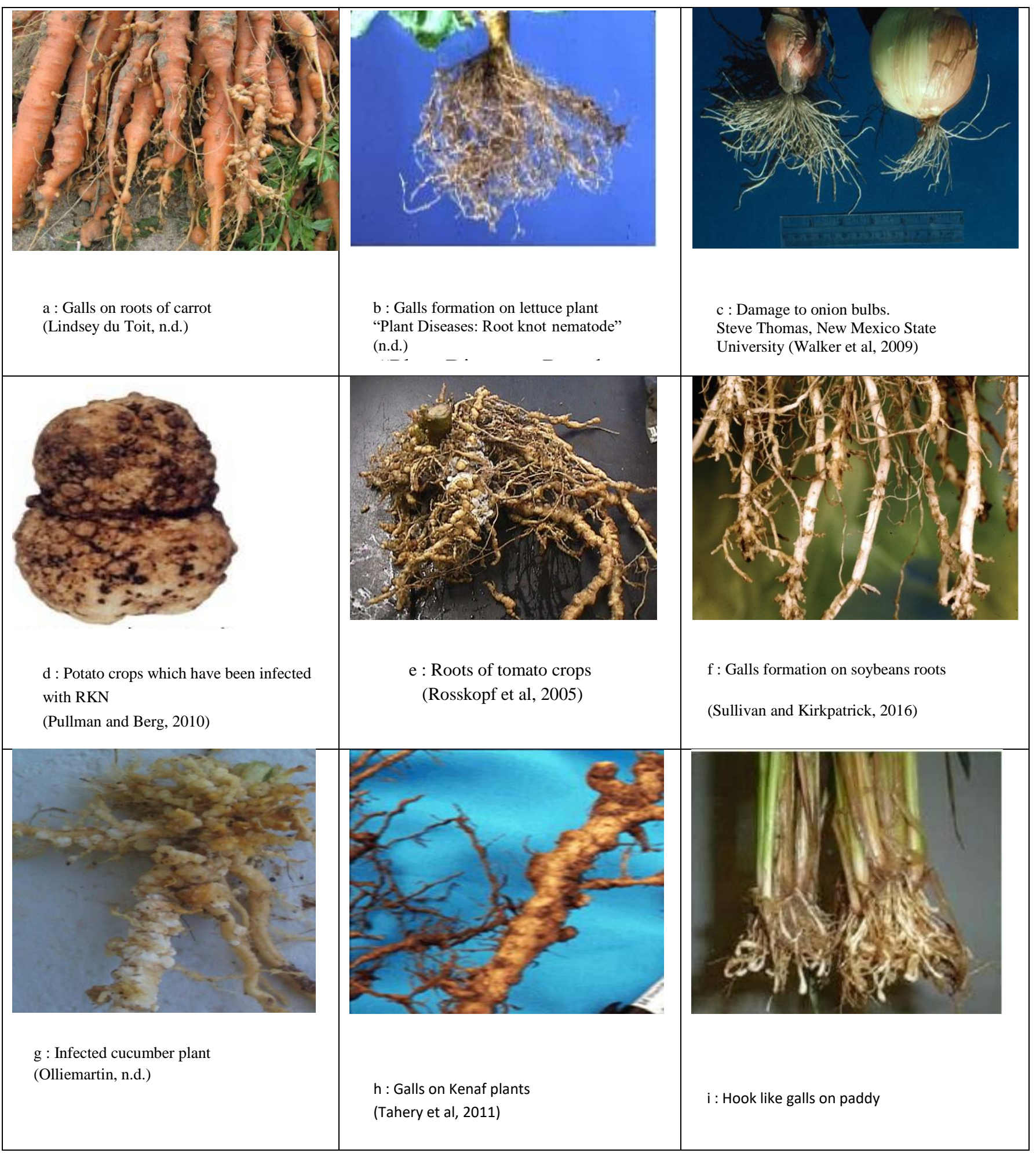

Fig 2. Different kind of crops infected with root knot nematode.

way they easily get in contact with nematode. A zone of protection for seed germination, transplant and new roots should be established by placing nematicides within the top 2-4 inches of soil. However, nonfumigant nematicides require integrated use of other chemical pest control to manage other weeds, insect and pests.

According to (Noling, 2009), the use of soil fumigants has been more consistently effective than non-fumigants for control of root-knot and sting nematodes in Florida. In addition, the most effective fumigations occur when the soil is well drained, in seedbed condition, and at temperatures above $60^{\circ} \mathrm{F}$. This fumigants need to be applied at least 3 weeks before crops are planted because fumigants are phytotoxic to plants (Noling, 2009).

\section{The use of bacteria and fungi in combat nematode problem}

Biocontrol utilizing both bacteria and fungi that parasitize or trap nematodes also can be considered as one of the good control method. In experiment done by Manaku (1975), a natural soil bacterium, Bacillus penetrans can effectively control root knot nematodes. However, at that time, $B$. 
penetrans cannot be cultured on any bacteriological media, thus it is not suitable to become a biocontrol agent. New possible biocontrol agent, nematode trapping fungi have gained attention as these fungi normally trap nematodes as a nitrogen source using several different methods such as, adhesive traps, sticky conidia, or constricting rings (Jaffee, 2001). Vianene and Abawi, (2000), reported that application of Hirsutella rhossiliensis to soil reduced $\mathrm{J} 2$ invasion to lettuce seedlings. Therefore, this suggests that application of Verticillium chlamydosporium and Hirsutella rhossiliensis could be effective in killing $M$. hapla when these nematodes are present in soil at low level.

\section{Trap Cropping}

Trap cropping is a nematode management technique that has been tested periodically since the late 1800 s. Root-knots are induced to enter the root of host and establish a feeding site on the plant. Matured female nematode is unable to leave the plant root. Then, all the host are destroyed along with trapping nematode within the root. Some examples of trap crops are tomatoes, beans and carrots. After two weeks of planting, the crop is destroyed by tillage, such as hoeing, to destroy the root system and all the nematodes trapped within the soil (Westerdahl, 2007). This technique is not as an effective as the use of nematicide because not all nematodes are induced to enter the roots, making this technique not widely used in large commercial agriculture field. But for the home gardeners, this method helps in taking care of environmental issues with the avoiding used of chemical substance.

\section{Plant resistance}

Nowadays, new sources of genetic resistance to root-knot nematodes are frequently being identified. In plants with resistant gene, there is no development of the feeding site because a localized tissue undergo necrosis or hypersensitive response (HR) occurs at or near initial feeding site. Nematodes that fail to establish feeding sites either die or leave the roots (Milligan et al., 1998). In an experiment done by Corbett et al., (2011), the $\mathrm{Mi}-1.2$ resistance gene in tomato (Solanum lycopersicum) confers resistance against several species of root-knot nematodes (Meloidogyne spp.). It was shown that the presence of Mi-1.2 resistance gene in isogenic tomato cultivars confers a dramatic fitness benefit under heavy nematode pressure (200,000 eggs/plant). Besides that, many other resistance genes have also been identified that are effective against species of Meloidogyne. These include the $\mathrm{Mi} 2$ through Mi8 genes (all from Lycopersicon) and the Me and $\mathrm{N}$ genes from pepper (Mitkowsaki and Abawi, 2003).

\section{Conclusion}

Root knot nematode which came from Meloidogyne genus can cause severe damage to the crop. Most countries in the world faced the same problem regarding the infection of root knot nematode especially in tropical, subtropical and temperate region. Invasion of nematode starts with penetration to the roots, then they migrated to the vascular cylinder, where they initiate a series of damage in the root, resulting in the formation of galls. This affects the transportation of water and nutrient in plants. The degree of severity caused by root knot nematode depends on the host plants. The highly susceptible host plants enhanced the distribution of Meloidogyne spp. while the less susceptible suppress their development as well as reduced their distribution. Thus, it is important to know how this nematode affects specified crops, what types of species that contribute to the damaged and ways to overcome the problem of root knot infestation.

\section{Acknowledgements}

This research was supported by a grant from Fundamental Research Grant Scheme by Ministry Education of Malaysia (Project No. FRGS/2/2014/SG03/UNISZA/02/1).

\section{References}

Abad P, Favery B, Rosso MN, Castagnone-Sereno P (2003) Root-knot nematode parasitism and host response: Molecular basis of a sophisticated interaction. Mol Plant Pathology. 4: 217-224.

Aegerter B (2009) Root-knot nematodes in tomatoes. Country Western Farm Press,UC Cooperative Extension, San Joaquin.

Boiteux LS, Belter JG (2000) RAPD linkage map of the genomic region encompassing the root-knot nematode (Meloidogyne javanica) resistance locus in carrot. Theor Appl Genet. 100: 439-446.

Corbett BP, Jia L, Sayler RJ, Arevalo-Soliz LM, Goggin F (2011) The effects of root-knot nematode infection and Mimediated nematode resistance in tomato on plant fitness. J Nematology. 43: 82-89.

De Waele D, Elsen A (2007) Challenges in tropical plant namatology. Ann Rev Phytopathol. 45: 457-485.

Dutta TK, Ganguly AK, Gaur HS (2012) Global status of rice knot-nematode, Meloidogyne graminicola. African J Microbio Research. 6: 6016-6021.

Ferraz S, Mendes ML (1992) The root knot nematode. Infor Agropecu. 16: 43-45.

Gill HK, Mcsorley R (2011) Cover Crops for Managing Root-Knot Nematodes. University of Florida, IFAS Extension, ENY-063(July), 1-6.

Hartwig NL, Ammon HU (2002) Cover crops and living mulches. Weed Sci. 50: 688-699.

Jaffee B, Pearson D, Timm L (2001) Nematode- trapping fungi in conventionally and organic managed corn-tomato rotations. Mycologia. 93: 25-29.

Jenkins WR, Sasser JN (1960) Nematology. University of North Carolina, Drham. 480 pp.

Jones JT, Haegemen A, Danchin EGJ, Gaur HS, Helder J, Jones MGK, Kikuchi T, Palomares-Rius JE, Wesemael WML, Perry RN (2013) Top 10 plant-parasitic nematodes in molecular plant pathology. Mol Plant Pathol. 14: 946961.

Karajeh M (2008) Interaction of root-knot nematode (Meloidogyne Javanica) and tomato as affected by hydrogen peroxide. J Plant Prot Res. 48(2):2.

Maluf WR, Azevedo SM, Gomes LAA, Oleveira ACB (2002) Inheritance of resistance to the root knot nematode Meloidogyne javanica in lettuce. Genet Mol Res. 1(1):6471.

Manakau R (1980) Biological control of nematode pests by natural enemies. Annu Rev Phytopathol. 81: 415-440.

Milligan SB, Bodeau J, Yaghoobi J, Koloshian I, Zabel P, Williamson VM (1998) The root knot nematode resistance gene $\mathrm{Mi}$ from tomato is a member of the leucine zipper, nucleotide binding, leucine-rich repeat family of plant genes. Plant Cell. 10: 1307-1319.

Mitkowski NA, Abawi GS (2003) Root-knot nematodes. The Plant Health Instructor. DOI:10.1094/PHI-I-2003-0917-01 Revised2011 
http://www.apsnet.org/edcenter/intropp/lessons/Nematodes/ Pages/RootknotNematode.aspx (24/3)

Noling JW (2009) Nematode management in tomatoes, peppers and eggplant. University of Florida, IFAS Extension, ENY-032 (December), 1-15.

Noling JW (2012) Nematode management in carrots, University of Florida, IFAS Extension, ENY-021,1-13.

Olsen MW (2000) Root-knot Nematode. University of Arizona, Arizona Cooperative Extension, AZ1187 (November), 1-3.

Rahman L (2003) Root knot diseases and its control. Agfact, $1-10$.

St. Amand PC, Wehner TC (1991) Crop loss to 14 diseases in cucumber in North Carolina for 1983 to 1988. Cucurbit Genet Coop Rpt. 14: 15-17.

Tahery Y, Shukor NAA, Abdul-Hamid H, Abdullah MP, Norlia B (2011) Status of root knot nematode disease on kenaf cultivated on bris soil in Kuala Terengganu, Malaysia. World Applied Sci J. 15(9):1287-1295.

Taylor AL, Sasser JN (1978) Biology, identification and control of root-knot nematodes (Meloidogyne species). North Carolina University Graphics.

Tisserat N (2006) Root knot nematode of tomato. Fact sheets tomato -Extension plant pathology Kansas State University, Manhattan. Retrieved from http://www.plantpath.ksu.edu/ pages/extension

Trudgill DL, Blok VC (2001) Apomictic, polyphagous root knot nematode : exceptionally sucessful and damaging biotrophic root pathogens. Annu Rev Phytopathol. 39:5377.

Wesemael WML, Moenc M (2008) Quality damage on carrots (Daurus carota L.) caused by the root-knot nematode Meloidogyne chitwoodi. Nematology. 10:261270 .
Westerdahl BB (2007) Trap cropping for management of root knot nematode by home gardeners.University of California Cooperative Extension Tehama Country. Retrieved from http://cetehama.ucanr.edu/?impact $=718 \& \mathrm{a}=7816$

Westpal A, Xing L (2006) Diseases of soybean; root knot nematodes. Botany Plant Pathology, Purdue University.

Widmer TL, Ludwig JW, Abawi GS (1999) The northern root knot nematode on carrot, lettuce, and onion in New York. Vegetable MD Online, Cornell University, Geneva, New York.

Windstead NN, Sasser JN (1956) Reaction of cucumber varieties to five root knot nematode (Meloidogyne spp.). Plant Dis Rptr. 40: 272-275.

Vianene NM., Abawi GS (2000) Hirsutella rhossiliensisand and Verticillium chlamydosporium as biocontrol agents of the root-knot nematode Meloidogyne hapla on lettuce. J Nematol. 32(1) :85-100.

Zimmer RC, Walkof C (1968) Occurence of the northern root-knot nematode Meloidogyne hapla on field grown cucumber in Manitoba. Can Plant Dis Surv. 48: 154. 